\title{
Molecular and clinical analyses of Japanese patients with carbamoylphosphate synthetase 1 (CPS1) deficiency
}

\author{
Keiji Kurokawa · Tohru Yorifuji · Masahiko Kawai · Toru Momoi · \\ Hironori Nagasaka · Masaki Takayanagi · Keiko Kobayashi · Makoto Yoshino • \\ Tomoki Kosho · Masanori Adachi · Harumi Otsuka - Shigenori Yamamoto • \\ Toshiaki Murata $\cdot$ Akihito Suenaga $\cdot$ Tsutomu Ishii $\cdot$ Kihei Terada \\ Naoto Shimura $\cdot$ Kohji Kiwaki · Haruo Shintaku Masaru Yamakawa · \\ Hiroki Nakabayashi · Yosuke Wakutani $\cdot$ Tatsutoshi Nakahata
}

Received: 18 October 2006/ Accepted: 21 January 2007/ Published online: 20 February 2007

(C) The Japan Society of Human Genetics and Springer 2007

\begin{abstract}
Carbamoylphosphate synthetase I deficiency (CPS1D) is a urea-cycle disorder characterized by episodes of life-threatening hyperammonemia. Correct diagnosis is crucial for patient management, but is difficult to make from clinical presentation and
\end{abstract}

K. Kurokawa · T. Yorifuji $(\bowtie) \cdot$ M. Kawai · T. Nakahata Department of Pediatrics, Kyoto University Hospital,

54 Shogoin Sakyo, Kyoto 606-8507, Japan

e-mail: yorif@kuhp.kyoto-u.ac.jp

\section{T. Momoi}

Department of Pediatrics, Japanese Red Cross Society,

Wakayama Medical Center, Wakayama, Japan

H. Nagasaka · M. Takayanagi

Division of Metabolism, Chiba Children's Hospital,

Chiba, Japan

\section{K. Kobayashi}

Department of Molecular Metabolism

and Biochemical Genetics, Kagoshima University

Graduate School of Medical and Dental Sciences,

Kagoshima, Japan

\section{Yoshino}

Department of Pediatrics,

Kurume University School of Medicine,

Kurume, Japan

T. Kosho

Division of Clinical and Molecular Genetics,

Shinshu University Hospital, Matsumoto, Japan

\section{Adachi}

Department of Endocrinology and Metabolism,

Kanagawa Children's Medical Center,

Yokohama, Japan conventional laboratory tests alone. Enzymatic or genetic diagnoses have also been hampered by difficult access to the appropriate organ and the large size of the gene (38 exons). In this study, in order to address this diagnostic dilemma, we performed the largest

H. Otsuka

Department of Neonatology, Chiba Municipal Kaihin Hospital, Chiba, Japan

S. Yamamoto

Department of Pediatrics, Shimoshizu National Hospital, Chiba, Japan

T. Murata

Division of Nephrology and Rheumatology,

Department of Internal Medicine, Fukuoka University

School of Medicine, Fukuoka, Japan

A. Suenaga

Department of Internal Medicine, Kitakyushu Municipal

Yahata Hospital, Kitakyushu, Japan

T. Ishii

Department of Pediatrics, Fukushima Medical University, Fukushima, Japan

K. Terada

Department of Pediatrics, Kawasaki Medical School,

Kurashiki, Japan

N. Shimura

Department of Pediatrics, Dokkyo University

School of Medicine, Tochigi, Japan

K. Kiwaki

Department of Pediatrics, Kumamoto University Graduate School of Medical Sciences, Kumamoto, Japan 
mutational and clinical analyses of this disorder to date in Japan. Mutations in CPS1 were identified in 16 of 18 patients with a clinical diagnosis of CPS1D. In total, 25 different mutations were identified, of which 19 were novel. Interestingly, in contrast to previous reports suggesting an extremely diverse mutational spectrum, $31.8 \%$ of the mutations identified in Japanese were common to more than one family. We also identified two common polymorphisms that might be useful for simple linkage analysis in prenatal diagnosis. The accumulated clinical data will also help to reveal the clinical presentation of this rare disorder in Japan.

Keywords CPS1 deficiency $\cdot$ Mutation . Clinical presentation

\section{Introduction}

Carbamoylphosphate synthetase I (CPS1) is a mitochondrial matrix enzyme that catalyzes the first step of the urea cycle; synthesis of carbamoylphosphate from bicarbonate, ATP, and ammonia using a cofactor $\mathrm{N}$-acetylglutamate (NAG). Its genetic deficiency (CPS1D; MIM\# 237300; EC 6.3.4.16) is a rare autosomal recessive disorder (1 in 800,000 newborns in Japan) characterized by episodes of life-threatening hyperammonemia in the neonatal period. A fraction of patients with residual enzyme activity $(10-25 \%$ of normal) present later, usually but not necessarily, with less severe hyperammonemia (Summar 1998).

The prognosis of patients with neonatal-onset hyperammonemia is generally poor. Most often, the serum ammonia level at initial presentation is high enough to cause irreversible brain damage, and many patients die of brain edema despite intensive medical care. Therefore, for a couple with a previous pregnancy involving a severely affected newborn, prenatal diagnosis is the only practical approach to cope with the problem of recurrence risk.

However, prenatal diagnosis has been hampered by several factors intrinsic to the CPS1 gene. Firstly, the gene is expressed mostly in the hepatocytes and, to a lesser degree, in the epithelial cells of the intestinal mucosa. Therefore, neither amniotic cells, amniotic fluid, nor chorionic villi can be used as a source of

\section{H. Shintaku}

Department of Pediatrics, Osaka City University Graduate

School of Medicine, Osaka, Japan

M. Yamakawa

Department of Pediatrics, Kobe City General Hospital,

Kobe, Japan enzyme assay, making a biochemical prenatal diagnosis practically impossible. Secondly, molecular diagnosis also is hampered by the large size of the gene. The CPS1 gene spans approximately $122 \mathrm{~kb}$ on chromosome 2q35 and consists of 38 exons (Hoshide et al. 1995; Summar 1998; Summar et al. 1995, 2003; Haraguchi et al. 1991). Because of the large size of the gene, mutational analyses of affected individuals have been reported for only 33 cases worldwide (Summar 1998; Häberle and Koch 2004; Häberle et al. 2003; Rapp et al. 2001; Finckh et al. 1998; Funghini et al. 2003), fewer in Japan (Wakutani et al. 2004; Aoshima et al. 2001a, b; Hoshide et al. 1993; Ihara 1999), and without a known common mutation, molecular diagnosis has been unavailable for most affected families. Thirdly, the clinical diagnostic criteria of CPS1D, i.e., hyperammonemia associated with low/absent serum citrulline and urinary orotic acid excretion, cannot discriminate CPS1D from another disorder, $\mathrm{N}$-acetylglutamate synthetase (NAGS) deficiency. For a correct diagnosis of CPS1D, either enzymatic diagnosis using the patient's liver or molecular diagnosis to detect mutations in the CPS1 gene is mandatory.

In this study, as an initial approach to address this diagnostic dilemma, we accumulated patients from across Japan diagnosed as having CPS1D, and performed clinical and mutational analyses to establish the mutational spectrum and possible genotype-phenotype correlations of CPS1D in this country.

\section{Materials and methods}

\section{Subjects}

The study subjects were 18 Japanese cases with a clinical diagnosis of CPS1D, 15 with neonatal-onset type and three with later onset (Table 1). Written informed consent was obtained from each subject or their parents and the study protocol was approved by the institutional review board of Kyoto University Hospital.

DNA analysis

Genomic DNA was extracted from the patients' liver or from peripheral blood lymphocytes using the

H. Nakabayashi

Department of Pediatrics, Nihon University Surugadai

Hospital, Tokyo, Japan

Y. Wakutani

Department of Neurology, Institute of Neurological

Sciences, Tottori University, Yonago, Japan 
Table 1 Summary of clinical presentation and mutational analyses of carbamoylphosphate synthetase I deficiency (CPS1D) patients. Recurrent mutations are shown in bold type

\begin{tabular}{|c|c|c|c|c|c|c|c|c|}
\hline Patient & Sex & Onset & $\begin{array}{l}\text { Ammonia } \\
\text { at presentation } \\
(\mu \mathrm{g} / \mathrm{dl})\end{array}$ & $\begin{array}{l}\text { Plasma } \\
\text { citrulline } \\
(\mu \mathrm{mol} / \mathrm{l})\end{array}$ & Outcome & $\begin{array}{l}\text { Hepatic } \\
\text { enzyme } \\
\text { activity }\end{array}$ & $\begin{array}{l}\text { Mutation } 1 \\
\text { (exon, amino } \\
\text { acid change) }\end{array}$ & $\begin{array}{l}\text { Mutation } 2 \\
\text { (exon, amino } \\
\text { acid change) }\end{array}$ \\
\hline \multicolumn{9}{|c|}{ This study } \\
\hline 1 & M & Day 0 & 1,960 & 3.6 & Death on day 13 & $\mathrm{NA}^{\mathrm{a}}$ & $\begin{array}{l}\text { c.2945G > A } \\
(24, \text { G982D })\end{array}$ & $\begin{array}{l}\text { c. } 3723 \mathrm{C}>\mathrm{A} \\
\quad(31, \mathrm{~N} 1241 \mathrm{~K})\end{array}$ \\
\hline 2 & $\mathrm{~F}$ & Day 2 & 1,440 & 8.9 & Death on day 36 & Low & $\begin{array}{l}\text { c.2945G > A } \\
(24, \text { G982D) }\end{array}$ & Not detectable \\
\hline 3 & M & Day 1 & $>1,000$ & NA & Death on day 4 & Undetectable & $\begin{array}{l}\text { c.1528delG } \\
\quad(14, \text { fs514X) }\end{array}$ & $\begin{array}{l}\text { c.1528delG } \\
\quad(14, \text { fs514X) }\end{array}$ \\
\hline 4 & $\mathrm{~F}$ & 13 years & 938 & Low & $\begin{array}{l}\text { Alive (no mental } \\
\text { retardation) }\end{array}$ & $17 \%$ & $\begin{array}{l}\text { c.1528delG } \\
\quad(14, \text { fs514X) }\end{array}$ & $\begin{array}{l}\text { c. } 2021 \mathrm{~A}>\mathrm{T} \\
\quad(18, \mathrm{~N} 674 \mathrm{I})\end{array}$ \\
\hline 5 & M & Day 3 & 3,295 & NA & Death at age 1 years & NA & $\begin{array}{l}\text { c.130C > T } \\
\quad(2, Q 44 X)\end{array}$ & $\begin{array}{l}\text { c.3969insC } \\
\quad(33, \mathrm{fs} 1328 \mathrm{X})\end{array}$ \\
\hline 6 & M & Day 1 & 2,376 & 8.2 & Death on day 20 & NA & $\begin{array}{l}\text { c.130C > T } \\
\quad(2, Q 44 X)\end{array}$ & $\begin{array}{l}\text { c. } 1312 \mathrm{G}>\mathrm{C} \\
\quad(13, \mathrm{~A} 438 \mathrm{P})\end{array}$ \\
\hline 7 & $\mathrm{~F}$ & Day 3 & 3,197 & 6.288 & $\begin{array}{l}\text { Alive (severe mental } \\
\text { retardation) }\end{array}$ & NA & $\begin{array}{l}\text { c.2359C > T } \\
(19, \text { R787X) }\end{array}$ & $\mathrm{IVS} 2+6 \mathrm{~T}>\mathrm{C}$ \\
\hline 8 & M & Day 2 & $>1,000$ & TR & Death on day 14 & NA & $\begin{array}{l}\text { c.2359C > T } \\
(19, \text { R787X) }\end{array}$ & $\begin{array}{l}\text { c. } 3093 \mathrm{C}>\mathrm{A} \\
\quad(25, \mathrm{Y} 1031 \mathrm{X})\end{array}$ \\
\hline 9 & M & Day 1 & 1,402 & NA & Death on day 12 & Undetectable & $\begin{array}{l}\text { c. } 840 \mathrm{G}>\mathrm{C} \\
\quad(8, \mathrm{~K} 280 \mathrm{~N})\end{array}$ & Not detectable \\
\hline 10 & $\mathrm{~F}$ & Day 3 & 1,370 & 5.3 & $\begin{array}{l}\text { Alive (no mental } \\
\text { retardation) }\end{array}$ & NA & $\begin{array}{l}\text { c. } 1760 \mathrm{G}>\mathrm{A} \\
\quad(16, \mathrm{R} 587 \mathrm{H})\end{array}$ & $\begin{array}{l}\text { c.2494delGinsAA } \\
\text { (fs836X) }\end{array}$ \\
\hline 11 & $\mathrm{~F}$ & Day 2 & 4,400 & Low & Death on day 60 & NA & $\begin{array}{l}\text { c. } 3784 \mathrm{C}>\mathrm{T} \\
\quad(32, \mathrm{R} 1262 \mathrm{X})\end{array}$ & $\begin{array}{l}\text { c. } 2548 \mathrm{C}>\mathrm{T} \\
\quad(20, \mathrm{R} 850 \mathrm{C})\end{array}$ \\
\hline 12 & M & Day 1 & $>400$ & 5.7 & Death on day 6 & Undetectable & $\begin{array}{l}\text { c. } 1777 \mathrm{G}>\mathrm{C} \\
\quad(16, \mathrm{G} 593 \mathrm{~A})\end{array}$ & $\begin{array}{l}\text { c.2494insT } \\
\text { (fs999X) }\end{array}$ \\
\hline 13 & $\mathrm{~F}$ & 31 years & 3,593 & 34.9 & Death at age 31 years & NA & $\begin{array}{l}\text { c. } 634 \mathrm{~T}>\mathrm{A} \\
\quad(7, \mathrm{Y} 212 \mathrm{~N})\end{array}$ & $\begin{array}{l}\text { c.3308A > G } \\
\quad(26, \text { Q1103R })\end{array}$ \\
\hline 14 & $\mathrm{~F}$ & Day 2 & 2,320 & Undetectable & Death on day 4 & Undetectable & $\begin{array}{l}\text { c.860delA } \\
\quad(9, \text { fs } 298 X)\end{array}$ & $\begin{array}{l}\text { c. } 3643 \mathrm{~A}>\mathrm{G} \\
\quad(30, \mathrm{I} 1215 \mathrm{~V})\end{array}$ \\
\hline 15 & $\mathrm{~F}$ & Day 1 & $>1,000$ & 18.7 & Death on day 2 & NA & $\begin{array}{l}\text { c. } 236 \mathrm{G}>\mathrm{A} \\
(2, \mathrm{G} 79 \mathrm{E})\end{array}$ & $\begin{array}{l}\text { c. } 3584 \mathrm{~A}>\mathrm{C} \\
\quad(30, \mathrm{H} 1195 \mathrm{P})\end{array}$ \\
\hline 16 & $\mathrm{~F}$ & Day 2 & 1,001 & NA & $\begin{array}{l}\text { Liver transplantation, } \\
\text { no mental } \\
\text { retardation }\end{array}$ & $6.25 \%$ & $\begin{array}{l}\text { c. } 1951 \mathrm{G}>\mathrm{A} \\
\quad(17, \mathrm{E} 651 \mathrm{~K})\end{array}$ & $\begin{array}{l}\text { c. } 2339 \mathrm{G}>\mathrm{A} \\
\quad(19, \mathrm{R} 780 \mathrm{H})\end{array}$ \\
\hline 17 & M & Day 2 & 404 & 3.8 & $\begin{array}{l}\text { Severe mental } \\
\text { retardation }\end{array}$ & $30 \%$ & Not detectable & Not detectable \\
\hline 18 & $\mathrm{~F}$ & 45 years & 263 & 2.8 & $\begin{array}{l}\text { Liver dysfunction } \\
\text { mild metal } \\
\text { retardation, } \\
\text { epilepsy }\end{array}$ & $39 \%$ & Not detectable & Not detectable \\
\hline \multicolumn{9}{|c|}{ Previously reported cases } \\
\hline $19^{\mathrm{b}}$ & $\mathrm{F}$ & Day 2 & 956 & NA & Death on day 4 & $11 \%$ & $\begin{array}{r}\text { c.840G > C } \\
(\mathrm{K280N})\end{array}$ & $\begin{array}{r}\text { c.840G > C } \\
(\mathrm{K} 280 \mathrm{~N})\end{array}$ \\
\hline $20^{\mathrm{c}}$ & NA & NA & NA & NA & NA & NA & $\begin{array}{c}\text { c.130C }>\text { T } \\
(\mathbf{Q 4 4 X )}\end{array}$ & NA \\
\hline $21^{\mathrm{d}}$ & $\mathrm{F}$ & 13 years & 676 & Undetectable & $\begin{array}{l}\text { Intermittent } \\
\text { hyper-ammonemia. } \\
\text { Alive at } 18 \text { years }\end{array}$ & $4.8 \%$ & $\begin{array}{r}\text { c. } 3422 \mathrm{~T}>\mathrm{G} \\
(\mathrm{V} 1141 \mathrm{G})\end{array}$ & $\begin{array}{r}\text { c. } 3784 \mathrm{C}>\mathrm{T} \\
(\mathrm{R} 1262 \mathrm{X})\end{array}$ \\
\hline $22^{\mathrm{d}}$ & NA & $<1$ week & NA & NA & Death $<1$ week & NA & $\begin{array}{l}\text { c.1528delG } \\
\quad(14, \text { fs514X) }\end{array}$ & $\begin{array}{l}\text { c. } 2752 \mathrm{~T}>\mathrm{C} \\
\quad(\mathrm{S} 918 \mathrm{P})\end{array}$ \\
\hline $23^{\mathrm{d}}$ & NA & Day 2 & 4079 & Undetectable & Death on day 24 & Undetectable & $\begin{array}{l}\text { c. } 2549 \mathrm{G}>\mathrm{A} \\
(\mathrm{R} 850 \mathrm{H})\end{array}$ & $\begin{array}{r}\text { c.2797delT } \\
(\mathrm{L} 933 \mathrm{X})\end{array}$ \\
\hline $24^{\mathrm{e}}$ & $\mathrm{F}$ & Day 9 & 1,550 & Low & $\begin{array}{l}\text { Severely retarded } \\
\text { at } 27 \text { months }\end{array}$ & Undetectable & $\begin{array}{l}\text { c. } 1010 \mathrm{~A}>\mathrm{G} \\
(\mathrm{H} 337 \mathrm{R})\end{array}$ & $4.2 \mathrm{~kb}$ del \\
\hline
\end{tabular}


Table 1 continued

\begin{tabular}{|c|c|c|c|c|c|c|c|c|}
\hline Patient & Sex & Onset & $\begin{array}{l}\text { Ammonia } \\
\text { at presentation } \\
(\mu \mathrm{g} / \mathrm{dl})\end{array}$ & $\begin{array}{l}\text { Plasma } \\
\text { citrulline } \\
(\mu \mathrm{mol} / 1)\end{array}$ & Outcome & $\begin{array}{l}\text { Hepatic } \\
\text { enzyme } \\
\text { activity }\end{array}$ & $\begin{array}{l}\text { Mutation } 1 \\
\text { (exon, amino } \\
\text { acid change) }\end{array}$ & $\begin{array}{l}\text { Mutation } 2 \\
\text { (exon, amino } \\
\text { acid change) }\end{array}$ \\
\hline $25^{\mathrm{f}}$ & M & Day 3 & 1,970 & Low & Death on day 28 & $6 \%$ & $\begin{array}{c}\text { c.840G > C } \\
(\mathrm{K} 280 \mathrm{~N})\end{array}$ & $\begin{array}{c}\text { c. } 1123 \mathrm{C}>\mathrm{T} \\
(\mathrm{Q} 375 \mathrm{X})\end{array}$ \\
\hline
\end{tabular}

${ }^{a}$ Not available

b Hoshide et al. 1995

c Ihara 1999

d Wakutani et al. 2004

e Aoshima et al. 2001a

f Aoshima et al. 2001b

QIAmp DNA Mini Kit (Qiagen, Hilden, Germany). Then, all 38 exons of the CPS1 gene were amplified together with the exon-intron boundaries in $25 \mu \mathrm{l}$ reactions containing $50 \mathrm{ng}$ genomic DNA, $10 \mathrm{mM}$ Tris$\mathrm{HCl}, \mathrm{pH} 8.3,50 \mathrm{mM} \mathrm{KCl}, 2.5 \mathrm{mM} \mathrm{MgCl}_{2}, 0.01 \%$ (w/v) gelatin, 12.5 pmol of each primer, and $0.5 \mathrm{U}$ AmpliTaq Gold DNA polymerase (Perkin-Elmer, Wellesley, MA). Initial denaturation at $94^{\circ} \mathrm{C}$ for $10 \mathrm{~min}$ was followed by 30 cycles of denaturation at $94^{\circ} \mathrm{C}$ for $30 \mathrm{~s}$, annealing at $55^{\circ} \mathrm{C}$ for $30 \mathrm{~s}$ and extension at $72^{\circ} \mathrm{C}$ for $30 \mathrm{~s}$. The sequences of the amplification primers are available on request. Amplification products were purified using the Wizard PCR Preps DNA Purification System (Promega, Madison, WI) and directly sequenced using the Big Dye Terminator v3.1 Cycle Sequencing Kit with one of the amplification primers. The sequence was determined using an ABI Prism 3100 Genetic Analyzer (Applied Biosystems, Foster City, CA). Since there were polymorphic $\mathrm{T}$ stretches on both flanking regions of exon 30 , we subcloned this fragment into the pCR2.1 plasmid with the TOPO TA cloning Kit (Invitrogen, Carlsbad, CA) and sequenced multiple clones.

\section{Results}

Table 1 summarizes the results of mutational analyses together with the clinical presentation of each patient. Of the 18 cases referred to us under the diagnosis of suspected CPS1 deficiency, mutations in the CPS1 gene were identified in 16 patients at least in one allele, thus confirming the diagnosis of CPS1D. In two of the patients mutations could not be identified although both patients showed lower hepatic CPS1 activities.

Plasma citrulline levels were usually low, although the value could be as high as $34.9 \mu \mathrm{mol} / \mathrm{l}$ (case 13), which is well within the normal range $(22-25 \mu \mathrm{mol} / \mathrm{l})$.
As previously described for other ethnic groups (Summar 1998), most (14 out of 16) of these patients presented in the neonatal period with severe hyperammonemia, while the other two patients (cases 4 and 13) presented later in life. Except for three patients (cases $7,10,16$ ), patients with neonatal onset died very early in life despite intensive therapy including protein restriction, hemodialysis/peritoneal dialysis, and nitrogen disposal medications such as sodium benzoate, sodium phenylacetate, or arginine. Two of the survivors (cases 10 and 16) are still alive, and have normal psychomotor development despite initial hyperammonemia exceeding $1,000 \mu \mathrm{g} / \mathrm{dl}$. One was treated with sodium benzoate, L-carnitine, arginine, and dietary protein restriction while the other underwent liver transplantation. On the other hand, the prognosis of patients with later onset is not necessarily favorable. One of the late-onset cases, case 13, presented with fatal hyperammonemia $(3,593 \mu \mathrm{g} / \mathrm{dl})$ at initial diagnosis (31 years). The other patient with late-onset presentation (case 4) is alive, is without psychomotor delay and is treated with sodium benzoate, L-carnitine, arginine, and dietary protein restriction.

In these 16 patients, 25 different mutations were identified. The mutations consisted of 14 missense, 4 nonsense, 2 splice-site, and 5 in/del mutations. Six of these mutations have been previously reported while the other 19 were novel; none of these novel mutations have been listed in the public SNP databases, dbSNP (http://www.ncbi.nlm.nih.gov/) and JSNP (http://www.snp.ims.u-tokyo.ac.jp/). Although no prevalent "common" mutation was identified, some of the mutations were shared by more than one family, probably reflecting relatively common mutations among Japanese.

Figure 1 describes the position of these mutations in relation to previously identified functional domains of the CPS1 molecule (Yefimenko et al. 2005). All but two missense mutations (G79E and Y212N) were 
Fig. 1 Structure of the carbamoylphosphate synthetase I (CPS1) molecule and distribution of identified mutations. The Unknown function domain corresponds to the amidotransferase domain of Escherichia coli CPS

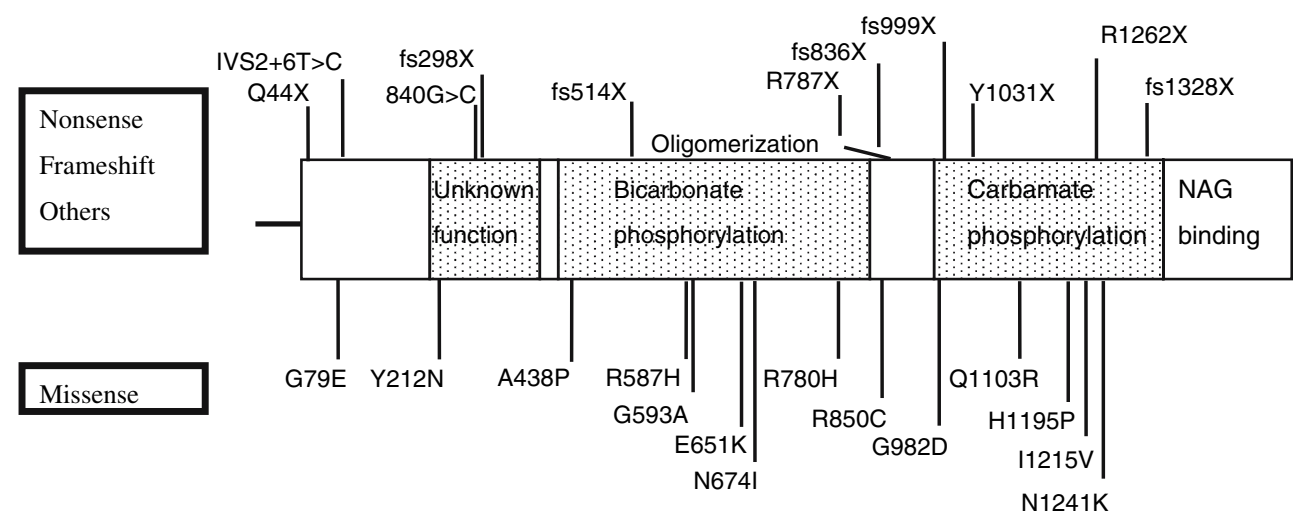

clustered around the two phosphorylation domains, while the nonsense and in/del mutations are scattered throughout the gene. The clinical significance of IVS2 $+6 \mathrm{~T}>\mathrm{C}$ remains unknown since we could not perform transcript analyses for this apparent splice-site mutation. The mutation, however, is not listed in public SNP databases (DBSNP and JSNP) and could not be found in 50 normal Japanese volunteers, and the calculated splice-site score (http://www.fruitfly.org/seq_tools/splice.html) dropped to 0.70 as compared with 0.99 in the wild-type sequence. In addition to these mutations, we identified a previously unidentified common polymorphism, -3insTTC, in nine patients.

\section{Discussion}

In this study, we present the largest series of molecular and clinical analyses of Japanese patients with CPS1 deficiency to date. Table 1 summarizes the results of our study together with seven previously reported Japanese cases. Combining these results together reveals the characteristics of the mutational and clinical spectra of CPS1D in Japan.

Previously, it has been reported that most CPS1 mutations were specific to individual families and only two mutations were shared by more than one family: N716K (Summar 1998) and 840G > C (Hoshide et al. 1993; Aoshima et al. 2001a, b). However, of the 25 mutations detected in our series, 7 were shared by multiple CPS1D families: 2945G $>$ A (G982D) in cases 1 and 2, 1528delG (fs514X) in cases 3, 4, and 22, $130 \mathrm{C}>\mathrm{T}(\mathrm{Q} 44 \mathrm{X})$ in cases 5, 6, and 20, 840G $>\mathrm{C}$ in cases 9,19 , and $25,3784 \mathrm{C}>\mathrm{T}(\mathrm{R} 1262 \mathrm{X})$ in cases 11 and 21. In addition, two of the Japanese mutations, $1760 \mathrm{G}>\mathrm{A}(\mathrm{R} 587 \mathrm{H})$ and $2359 \mathrm{C}>\mathrm{T}(\mathrm{R} 787 \mathrm{X})$, were identical to mutations previously reported by Summar (1998) and Rapp et al. (2001), respectively. Mutations of CPS1 in Japan, therefore, consist of recurrent mutations common to multiple families as well as strictly individual mutations. However, even if all these relatively common mutations are combined, they account for only $31.8 \%$ (14/44) of the mutations in Japan, and the mutational spectrum is still scattered widely in the CPS1 gene. The geographical distribution of these common mutations is also scattered widely, except that three out of four patients with Q44X came from Kyushu Island. In this regard, a common polymorphism identified in this study, -3insTTC, could be useful for simple intrafamilial linkage analysis in prenatal diagnosis as long as the diagnosis of the proband is confirmed. The T-stretches in both flanking introns of exon 30 were also polymorphic with 11-14 Ts on the $5^{\prime}$ side and 13-16 Ts on the $3^{\prime}$ side. However, the usefulness of these T-stretches might be limited since they were extremely error-prone in the amplification process probably due to slippage of the DNA polymerase. It was hard to determine the $\mathrm{T}$ number by direct sequencing of the amplification products, and, when cloned into a plasmid and sequenced, we often observed three or more clones with different $\mathrm{T}$ repeats from a single patient.

Since only three Japanese cases of late-onset CPS1D have been analyzed for mutations (two in this study and one in a previous study), genotype-phenotype correlation is not evident at present.

Of interest are the two patients for whom clinical diagnoses of CPS1D were made, yet no mutations were identified in the coding region of the CPS1 gene. Either they have mutations undetectable by our assay, such as large deletions or promoter mutations, or they could actually have NAGS deficiency rather than CPS1D. Both patients are reported to have low hepatic CPS1 activity; however, Yoshino et al. (1997) have shown that even with low hepatic enzyme activity, the diagnosis of CPS1D is not always certain. Further analyses are necessary to address the questions of how accurate are clinical diagnoses and what percentage of patients actually have NAGS deficiency rather than CPS1D? 
Acknowledgments We are grateful to the families who participated in the study. We also thank the following doctors who referred the patients, Drs Hidemasa Hayashibe (Department of Pediatrics, Yamanashi University School of Medicine), Yoichi Murakami (Department of Pediatrics, Kitakami Saiseikai Hospital), Atsuko Ishihara and Mitsuyoshi Okumura (Department of Pediatrics, Japanese Red Cross Society Wakayama Medical Center).

\section{References}

Aoshima T, Kajita M, Sekido Y, Kikuchi S, Yasuda I, Saheki T, Watanabe K, Shimokata K, Niwa T (2001a) Novel mutations (H337R and 238-362 del) in the CPSI gene cause carbamoyl phosphate synthetase I deficiency. Hum Hered 52:99-101

Aoshima T, Kajita M, Sekido Y, Mimura S, Itakura A, Yasuda I, Saheki T, Watanabe K, Shimokata K, Niwa T (2001b) Carbamoyl phosphate synthetase I deficiency: molecular genetic findings and prenatal diagnosis. Prenat Diagn 21:634-637

Finckh U, Kohlschutter A, Schafer H, Sperhake K, Colombo JP, Gal A (1998) Prenatal diagnosis of carbamoyl phosphate synthetase deficiency of a missense mutation in CPS I. Hum Mutat 12:206-211

Funghini S, Donati MA, Pasquini E, Zammarchi E, Morrone A (2003) Structural organization of the human carbamoyl phosphate synthetase I gene (CPS1) and identification of two novel genetic lesions. Hum Mutat 22:340-341

Häberle J, Koch HG (2004) Genetic approach to prenatal diagnosis in urea cycle defects. Prenat Diagn 24:378-383

Häberle J, Schmidt E, Pauli S, Rapp B, Christensen E, Wermuth B, Koch HG (2003) Gene structure of carbamoylphosphate synthetase 1 and novel mutations in patients with neonatal onset. Hum Mutat 21:444-449

Haraguchi Y, Uchino T, Takiguchi M, Endo F, Mori M, Matsuda I (1991). Cloning and sequence of a cDNA encoding human carbamyl phosphate synthetase I: molecular analysis of hyperammonemia. Gene 107:335-340

Hoshide R, Matsuura T, Haraguchi Y, Endo F, Yoshinaga M, Matsuda I (1993) Carbamoyl phosphate synthetase I defi- ciency. One base substitution in an exon of the CPS I gene causes a 9-basepair deletion due to aberrant splicing. J Clin Invest 91:1884-1887

Hoshide R, Soejima H, Ohta T, Niikawa N, Haraguchi Y, Matsuura T, Endo F, Matsuda I (1995) Assignment of the human carbamoyl phosphate synthetase I gene (CPS I) to $2 \mathrm{q} 35$ by fluorescence in situ hybridization. Genomics 28:124-125

Ihara K, Nakayama H, Hikino S, Hara T (1999) Mutation in CPS I. Hum Genet 105:375

Rapp B, Haberle J, Linnebank M, Wermuth B, Marquardt T, Harms E, Koch HG (2001) Genetic analysis of carbamoylphosphate synthetase I and ornithine transcarbamylase deficiency using fibroblasts. Eur J Pediatr 160:283-287

Summar ML (1998) Molecular genetic research into carbamoylphosphate synthetase I: molecular defects and linkage markers. Inher Metab Dis 21:30-39

Summar ML, Dasouski MJ, Schofield PJ, Krishnamani MRS, Vnencak-Jones C, Tuchman M, Mao J, Phillips III JA (1995) Physical and linkage mapping of human carbamoyl phosphate synthetase I (CPS I) and reassignment from $2 p$ to 2q35. Cytogenet Cell Genet 71:266-267

Summar ML, Hall LD, Eeds AM, Hutcheson HB, Kuo AN, Willis AS, Rubio V, Arvin MK, Schofield JP, Dawson EP (2003) Characterization of genomic structure and polymorphisms in the human carbamoyl phosphate synthetase I gene. Gene 311:51-57

Wakutani Y, Nakayasu H, Takeshima T, Adachi M, Kawataki M, Kihira K, Sawada H, Bonno M, Yamamoto H, Nakashima K (2004) Mutational analysis of carbamoylphosphate synthetase I deficiency in three Japanese patients. J Inher Metab Dis 27:787-788

Yefimenko I, Fresquet V, Marco-Marin C, Rubio V, Cervera J (2005) Understanding carbamoyl phosphate synthetase deficiency: impact of clinical mutations on enzyme functionality. J Mol Biol 349:127-141

Yoshino M, Nishiyori A, Koga Y, Mizushima Y, Maeshiro H, Inoue T, Izumi S, Hatase T, Yakushiji M, Kato H (1997) Potential pitfall of enzymatic diagnosis of carbamoyl-phosphate synthetase I deficiency. J Inher Metab Dis 20:711-712 